\title{
Determinants of Corporate Social Disclosures in Kenya: A Longitudinal Study of Firms Listed on the Nairobi Securities Exchange
}

\author{
Muturi Wachira \\ Faculty of Business Studies, St. Paul's University, Limuru, Kenya
}

doi: 10.19044/esj.2017.v13n11p112 URL:http://dx.doi.org/10.19044/esj.2017.v13n11p112

\begin{abstract}
This study which was exploratory in nature aimed to examine the extent to which firms listed on the Nairobi Securities Exchange disclosure social responsibility information and also to determine company and corporate governance variables that influence the Corporate Social Disclosures (CSD) practice in Kenya. Data on the disclosure index and company characteristics were obtained from the annual reports of the respective companies. A relationship between the disclosure index and the various company characteristics was determined. It was found that size, profitability, liquidity, industry in which a company operates have a positive influence on the level of CSD. In addition, a company that a dispersed ownership disclosed more information than a company with concentrated ownership. Gearing and country of origin were found to have no influence on the level of CSD.
\end{abstract}

Keywords: Corporate Social Disclosures, Corporate Social Responsibility, Agency Theory, Legitimacy Theory, Stakeholder Theory

\section{Introduction}

There is a growing global concern about the impact of businesses on society. This has mainly been brought about by the increasing concern of the influence businesses on the environment and the issue of climatic change. Society also expects more from the businesses than it did before. Businesses are now expected to be transparent and accountable, and that they should be involved in promoting societal wellbeing. This has led companies to have a need to inform society of what they are doing, which in turn has led to the development of Corporate Social Disclosure (CSD) practice.

CSD refers to information that is provided by a company about its interactions with society (Branco \& Rodrigues, 2006). CSD also refers to voluntary reporting of social and environmental information of a company's 
interactions with different stakeholders (Lim, Talha, Mohamed, \& Sallehhuddin, 2008). Companies may be involved in CSD so as to discharge a moral duty, gain competitive advantage, report the company's performance, improve the company's image (Buhr, 2007), and influence the external perceptions of the company (Deegan, 2002). Most of the studies indicate that CSD has been increasing over the years (Ratanajongkol, Davey, \& Low, 2006). However, not all companies have embraced it (Gray \& Bebbington, 2007) and its development has been somewhat slow and piecemeal (Ratanajongkol, Davey, \& Low, 2006).

Due to the fact that the CSD practice is largely unregulated and therefore not standardized, it has not developed similarly in different regions of the world (Salama, Cathcart, Andrews, \& Hall, 2006). Studies have shown that there are more social disclosures in the developed countries as compared to the developing countries and that the themes emphasized differ even in the developed countries. Majority of the researches on CSD have been done in the developed world. This study was therefore necessary in order to add to the growing literature on CSD in developing countries.

\section{Objective of the Study}

The purpose of the study was to determine the relationship between corporate social disclosures and various company characteristics and corporate governance variables.

\section{Literature Review \\ Corporate Social Disclosures}

The traditional financial reporting has mainly concentrated on the needs of the industry, finance and the market (Makris, 1996). Social responsibility accounting has emanated from the need for accounting to address the needs of all the firms' stakeholders. The growth of CSD has also been influenced by the fact that in the value creation process, firms are now relying more on intangibles and intellectual assets which are not properly captured in mandatory reporting (Braam \& Borghans, 2010). Social responsibility accounting is, therefore, complimentary to traditional historical accounting and helps in disclosing more information to various stakeholders.

CSD has been defined variously in accounting literature. Most of the CSD definitions are premised on the fact that companies have other reponsibilities in addition to making monies for the providers of capital. One of the earliest definitions is offered by Elias and Epstein (1975, p. 36) who define it as the "reporting on some aspects of the business organization's social activities, performance or impact". Others have defined it as information provided by a company about its interactions with society 
(Crawford \& Williams, 2010). It has also been referred to as the reporting of social and environmental information of a company's interactions with different stakeholders (Crawford \& Williams, 2010). These definitions can best be summed up by the definition by (Gray, Owen, and Adams (1996, p. 3) who define CSD as "the process of communicating the social and environmental effects of organisations' economic actions to particular interest groups within society and to society at large”.

It should be noted that though much of the CSD is voluntary (Crawford \& Williams, 2010), in recent years it is increasingly being embedded in the annual reports of corporations in order to address the needs of all stakeholders (Walker, Michael, \& Urmila, 2007), as well as to create public awareness on the role of corporations in the society (Ratanajongkol, Davey, \& Low, 2006). Stakeholders are demanding more transparency from the company in order to protect their interests in the corporation (Crawford \& Williams, 2010). This has become more critical due to the recent corporate scandals which have made it evident that a company's survival and competitiveness can be endangered by a single focus on shareholder wealth maximization (Drews, 2010). Managers also have become more aware of sustainability issues and want to make their contribution which can only be supported by the availability of reliable information (Burritt \& Schaltegger, 2010).

\section{CSD Theories}

Several theories can be used to explain CSD practice. The main theories are the agency theory, legitimacy theory, and the stakeholder theory.

\section{Agency theory}

The agency theory tries to explain the conflict that can arise between the management on the one hand and the owners on the other hand. The agency problem leads to information asymmetry where the management has more information about the company than the owners (Thakor, 1993). One way of dealing with the information asymmetry problem is good corporate governance practices (Melis, 2004). The other way is to disclose more information (Narayanan, Pinches, \& Kelm, 2000).

\section{The legitimacy theory}

Legitimacy has been described as the congruence between the society's value system and those of the organization (Dowling \& Pfeffer, 1975). The legitimacy theory is based on the premise that a company has a right to exist, and that this right is deserved by acting in accordance with the expectations of the society with which it interacts (Dowling \& Pfeffer, 1975). The basic notion of legitimacy theory is the concept of social contract 
which may be expressed or implied (Elmogla, 2009). According to this theory, firms do not have an inherent right to exist; they do so with society's permission (Ratanajongkol, Davey, \& Low, 2006). A firm is seen as a part of wider society in which it exists; which means, therefore, that the legitimacy theory is essentially a systems oriented theory.

According to Guthrie and Parker (1989), if the legitimacy theory holds true, then corporations will react by disclosing more information when there are major social and environmental events. This has been confirmed by a study by Deagan et al. (2002). According to O’Donovan (2002), organizations need to continually maintain their legitimacy because society's expectations change from time to time. The author also notes that different organisations have different levels of legitimacy to maintain. Legitimation strategies can be used to change the perceptions of the society about a company without changing the real activities of the organisation (Milne \& Patten, 2002).

\section{The stakeholder theory}

In the stakeholder theory, the organization is seen as part of a wider social system (Ratanajongkol, Davey, \& Low, 2006). The main argument of the stakeholder theory is that there are wider groups of stakeholders in a company other than shareholders and other investors (Sternberg, 1997). The theory also holds that the success of an organization is dependent on how it manages its relationships with various stakeholders (Elijido-Ten, 2009). The organization, therefore, needs to manage the various stakeholders who are affected by the organization or affect the decisions it makes (Freedman, 1983). It has been shown that the key drivers of CSR are stakeholder-related (Ernst \& Young, 2002).

CSD is used to inform on the firm's social performance to its internal and external stakeholders (Kaptein, 2007), serves as an input for dialogue between different stakeholders (Kaptein \& Van Tulder, 2003) and, therefore, is a means by which stakeholder relations are managed (Zadek, 2001).

\section{Nairobi Securities Exchange}

The Nairobi Securities Exchange (NSE) is the largest capital market in the East and Central Africa. It is also considered the third largest securities market in Africa. In 2016 there were over 50 companies listed on the exchange.

\section{Hypotheses Development \\ Gearing}

Empirical evidences on whether the level of financial leverage affects disclosure of information are contradictory. Some studies have found a 
positive association between CSD and gearing (Bradbury, 1992; Naser, 1998); others have not found any significant relationship between CSD and gearing (McKinnon \& Dalimunthe, 1993; Carson \& Simnett, 1997). For example, according to Ahmed and Nicholas (1994), companies in countries where financial institutions are the primary source of funds are likely to disclose more information if they have a higher level of gearing. Barako (2007) found that, in order to satisfy creditors and remove the suspicions of wealth transfer to shareholders, firms with higher level of gearing tend to disclose more information. Given the forgoing the following hypothesis was tested.

$H_{0}$ : $\quad$ There is no positive association between the level of CSD and the gearing level of the company

\section{Size of the company}

Many studies have shown that the company size is an important determinant of CSD (Lang \& Lundholm, 1993; Wallace \& Naser, 1995). According to Chow and Wong-Boren (1987) agency costs increase with firm size and therefore the need to provide more information. Watts and Zimmerman (1986) and Cowen, at al. (1987) have said that larger firms have higher political costs due to their visibility. Such firms are therefore likely to disclose more information to improve their corporate image (Firth, 1979a). Ahmend and Courtis (1999) found size to be the most important determinant of CSD.

$H_{0}$ : $\quad$ There is no positive association between the level of CSD and the size of the company

\section{Profitability}

High profitable firms are likely to disclose more information in order to distinguish themselves from less profitable firms (Akerlof, 1970). Several studies have shown that profitability and extent of disclosure are significantly associated (Wallace \& Naser, 1995; Owusu-Ansah, 1998). However, there are other studies that have not found any relationship between profitability and disclosures (Wallace, Nase, \& Mora, 1994).

$H_{0}$ : $\quad$ There is no positive association between the level of CSD and the profitability of the company

\section{Liquidity}

High liquidity companies are likely to disclose more social responsibility information because they want to publish their strong status (Abd-El Salam \& Weetman, 2003). There are, however, researchers who have opposite opinion arguing that low liquidity companies may disclose more information in order to satisfy the information requirements of 
stakeholders (Hussainery, Elsayed, \& Razik, 2011). Studies on whether the level of liquidity influences disclosure levels have been inconclusive. Cooke (1989) found a positive relationship, Belkaoui-Riahi and Kahl (1978) found no relationship, but Wallace et al. (1994) found a negative relationship between liquidity and the level of disclosures.

$H_{0}$ : $\quad$ There is no positive association between the level of CSD and the liquidity of the company

\section{Industry}

Companies in different industry types face different social pressures (Ness \& Mirza, 1991; Gao, 2009). Companies with a higher likelihood of impacting on the environment have a higher social pressure to disclose environmental information (Adams, Hill, \& Roberts, 1998; Uwalomwa, 2011). Companies with widely consumed products are also likely to disclose more social information (Branco \& Rodrigues, 2008). Studies by Patten (Patten, 1991), Roberts (1992) and Hackston and Milne (1996) have found a positive association between CSD and the type of industry in which the company operates.

$H_{0}$ : Level of CSD is not related to the industry to which the company belongs.

\section{Country of origin}

Literature shows that the country in which a company is operating in, affects the level of CSD by that company (Silberhorn \& Warren, 2007; Pratten \& Mashat, 2009). For example, Hame and Huse (1997), found that the country in which a company is operating, is an important factor influencing disclosure of corporate environmental information. Related to this is the country of origin. Studies have shown that subsidiaries of multinationals disclose more social information than their local counterparts. $H_{0}$ : Level of CSD is not higher for multinational companies.

\section{Ownership structure}

Companies with a dispersed ownership are likely to disclose more information because of the agency conflicts that are likely to emerge (Depoers, 2000). Where ownership is concentrated the investors are able to get information privately and therefore do not need a lot of disclosure (Archambault \& Archambault, 2003). Studies by Roberts (1992) and Ullmann (Ullmann, 1985) have found that the degree to which ownership is concentrated on the hands of many investors influence positively the level of CSD. 
$H_{0}$ : Level of CSD is not higher for companies with a more dispersed ownership structure

\section{Presence of non-executive directors}

The presence of non-executive directors helps increase the effectiveness of the board because they provide necessary checks and balances (Franks, Mayer, \& Renneboog, 2001) and this reduces conflict between different stakeholders (Fama \& Jensen, 1983). Various studies have shown that there is a positive relationship between the level of social disclosures and presence of non-executive directors (Chen \& Jaggi, 2000).

$H_{0}$ : Level of CSD is not higher for companies with a higher proportion of non-executive directors on the board

\section{Presence of dual leadership structure}

One of the issues of corporate governance is the leadership structure (whether the chair of the board is also the CEO). Where the two roles are combined the board is significantly impaired and, therefore, cannot function properly (Barako, 2007). The CEO can act in his/her best interest because the board cannot effectively supervise him/her. Some studies have shown that there is a negative relationship between the combined role and the extent of CSD (Forker, 1992).

$H_{0}$ : Level of CSD is not higher for companies with dual leadership structure

\section{Type of Auditor}

According to Watts and Zimmerman (1986) due to the risk that auditors face where not enough information is disclosed, they are likely to influence their client to disclose as much information as possible. Larger audit firms are likely to influence more disclosure than small audit firms because of risk to their reputation (DeAngelo, 1981). Several studies indicate that indeed this is the case by showing a positive relationship between the size of the audit firm and corporate disclosure.

$H_{0}$ : Level of CSD is not higher for companies audited by the big four audit firms

\section{Presence of Audit Committee}

According to McMullen (1996), an audit committee increases reliability of financial reporting. They are commonly viewed as monitoring mechanisms that improve the quality of information flow (Bradbury, 1990). Ho and Wong (2001b) have shown that there is a positive relationship between corporate disclosures and the presence of audit committees. 
$H_{0}$ : Level of CSD is not higher for companies with an audit committee of the board

\section{Research Methodology Disclosure Index}

Proxies such as disclosure indices (Botosan, 1997; Garcia-Meca \& Martinez, 2005) and content analysis (Williams, 1998) have been used to measure the extent of disclosures. In this study disclosure index was used to measure the CSD level.

In order to determine the disclosure index, an item got one point if it was disclosed (Bukh, Gormses, \& Mouritsen, 2001) but got a score of zero if it was not disclosed at all (Firth, 1979b). The disclosure index of a company was calculated as its score divided by the maximum score achievable (Tarmizi, 2007). This score was determined in a pilot study. The disclosure index was calculated using the following formula.

$$
D I_{j}=\frac{\sum d_{i}^{m}}{n_{j}} \times 100
$$

Where, $\mathrm{DI}_{\mathrm{j}}$ is the disclosure index for jth firm, $\mathrm{d}_{\mathrm{i}}$ is 1 if the item is disclosed and 0 is the item is not disclosed, $n_{j}$ is the maximum number of items that can be disclosed by jth firm. The items included in the disclosure index calculation were also determined in the pilot study. The disclosure index was un-weighted due to the fact that it is difficult to assign weights to different items.

In the calculation of the disclosure indices of different companies annual reports were used. The rationale for using annual reports is that though they are not the only source of disclosures they are the most important (Ho \& Wong, 2001a) and are likely to be linked to other disclosures (Lang \& Lundholm, 1993).

\section{Reliability, validity and transferability}

To test for and improve on reliability, the disclosure index calculated was compared to the disclosure index calculated by an independent evaluator. And to assure the validity, senior accountants from the companies, were asked to check the accuracy of the computed disclosure index and they all agreed that it properly reflected what was disclosed.

\section{Data Analysis \\ Descriptive statistics}

Descriptive statistics for dependent and independent variables were calculated in order to help explain the behaviour of the disclosures. Such descriptive statistics included the mean, maximum, minimum, standard deviation, skewness, and kurtosis. 


\section{Regression analysis}

The regression equation used panel data consisting of both crosssectional and time series observations for the period 2006 to 2011. Panel data, because of providing a large number of data points, reduces the collinearity among the independent variables and may also improve the efficiency of statistical estimates (Hsioa, 2003). However, it increases the degree of freedom. Panel data can help in detecting and measuring effects that cannot easily be observed in pure time-series or cross-sectional data and because of this it can be used to analyse dynamic changes (Gujarati, 2003).

Table 1: Descriptions of the Regression Model Variables

\begin{tabular}{|c|c|}
\hline Variables & Descriptions \\
\hline DI & Disclosure index \\
\hline GER & Gearing ratio \\
\hline SIZ & Size \\
\hline PRO & Profitability \\
\hline LIQ & Liquidity of the company \\
\hline IND & Industry to which the company belongs \\
\hline COU & Country in which the country belongs \\
\hline OWN & Ownership structure \\
\hline NED & Presence of non-executive directors \\
\hline DEL & Leadership structure \\
\hline AUD & Auditor type \\
\hline AUC & Presence of the audit committee of the board of directors \\
\hline$\varepsilon$ & Error term (residual value) \\
\hline
\end{tabular}

The model below was therefore tested.

$$
\begin{aligned}
D I=\beta_{0}+\beta_{1} \mathrm{GER}+\beta_{2} \mathrm{SIZ}+\beta_{3} \mathrm{PRO}+\beta_{4} \mathrm{LIQ}+\beta_{5} \mathrm{IND}+\beta_{6} \mathrm{COU} \\
+\beta_{7} \mathrm{OWN}+\beta_{8} \mathrm{NED}+\beta_{9} \mathrm{DEL}+\beta_{10} \mathrm{AUD}+\beta_{11} \mathrm{AUC}+\varepsilon
\end{aligned}
$$

\section{Findings and Analysis}

\section{Multivariate analysis}

In a panel data analysis, one has to choose whether to use the fixedeffects model or the random effects model. Hausman test (Hausman, 1978) is used to test whether the coefficients estimated by the fixed-effect model and the random effect model are the same. Significant $\mathrm{P}$ value shows that coefficients are different and therefore the fixed effect model should be used.

In this case the $\mathrm{Chi}^{2}(5)$ had a value of 30.11 and a Prob $>$ Chi2 $=0.001$. This means that the $\mathrm{Chi}^{2}$ was significant and therefore the fixed-effects model was the best model to use in the regression analysis. However, after running the fixed-effects regression some of the dummy variables that do not change over time get omitted from the model. A time-invariant variable is omitted from the fixed-effects model because such models are designed to study the causes of changes within the entity being studied (Kohler \& 
Kreuter, 2009). The regression analysis was therefore conducted using the random effect model and the results obtained are presented in Table 2.

Table 2: Regression Results

\begin{tabular}{|c|c|c|c|c|}
\hline Variables & Coefficient & Newey-West Standard Errors & T-test & $\mathrm{P}>|\boldsymbol{t}|$ \\
\hline Constant & 0.18 & 1.19 & 0.15 & 0.882 \\
\hline GER & -0.11 & 0.10 & -1.08 & 0.279 \\
\hline SIZ & 0.80 & 0.06 & 12.95 & 0.001 \\
\hline PRO & 0.19 & 0.06 & 2.99 & 0.003 \\
\hline LIQ & 0.29 & 0.12 & 2.54 & 0.012 \\
\hline OWN & 0.42 & 0.19 & 2.23 & 0.026 \\
\hline NED & 0.27 & 0.23 & 1.17 & 0.241 \\
\hline IN1 & -0.16 & 0.09 & -1.70 & 0.091 \\
\hline IN2 & -0.32 & 0.09 & -3.59 & 0.001 \\
\hline IN3 & -0.21 & 0.11 & -1.95 & 0.051 \\
\hline IN4 & -0.43 & 0.10 & -4.14 & 0.001 \\
\hline IN5 & -0.41 & 0.15 & -2.75 & 0.006 \\
\hline IN6 & -0.47 & 0.09 & -5.06 & 0.001 \\
\hline IN7 & -0.19 & 0.11 & -1.71 & 0.088 \\
\hline IN8 & -0.09 & 0.13 & -0.76 & 0.450 \\
\hline IN9 & -0.02 & 0.11 & -0.17 & 0.861 \\
\hline COU & -0.06 & 0.05 & -1.06 & 0.292 \\
\hline
\end{tabular}

The results presented in Table 2 indicate that size, profitability, liquidity, ownership, and the industry in which a company operates are significant at 5\% level of significance. Gearing of the company, presence of non-executive directors and whether a company is a multinational company or not, are not significant at 5\% level of significance. The data obtained for leadership structure, auditor type and the presence of an audit committee were the same for all studied companies and were, therefore, not used in the regression model.

\section{Discussion and conclusions \\ Size}

The finding in this study is that the size of the company influences positively the level of CSD. This finding is consistent with previous findings by Cowen et al. (1987), Patten (1991), Raar (2002) and, Stanwick and Stanwick (2006). Other researchers such as Roberts (1992), and Ratanajongkol et al. (2006), however, did not find a relationship between the size of the company and the level of CSD.

This finding agrees with the stakeholder theory which suggests that because of the many stakeholders they have, larger companies are likely to disclose more information (Cowen, Ferreri, \& Parker, 1987). It also agrees with the legitimacy theory because larger firms are likely to disclose more information to legitimize their actions (Brammer \& Pavelin, 2006). 


\section{Profitability}

Profitability was found to have a positive influence on the level of CSD. This finding agrees with findings from similar studies (Singhvi, 1967; Abu-Nasar \& Rutherford, 1994). The findings contradict findings by several researchers who have found a negative relationship between profitability and CSD (King \& Lenox, 2001). King and Lenox found that CSD reduces profitability because of the costs it entails. It also contradicts findings by Connelly and Limpaphayom (2004), and Stanwick and Stanwick (Stanwick \& Stanwick, 2006), who found no correlation between financial performance and CSD.

The positive association between profitability and CSD can be explained by legitimacy theory. Very profitable companies may disclose more information in order to justify the level of their reported profits (Haniffa \& Cooke, 2005). This positive association can also be explained using the agency theory. According to the agency theory, in order to justify their higher pay, managers in high profitable companies are likely to disclose more information (Inchausti, 1997; Giner, 1997).

\section{Liquidity}

Findings in this study indicate that liquidity has a positive influence on the level of CSD of a company. This finding agrees with Cooke (1989) who says that there is an association between high liquidity and greater levels of disclosures. It, however, disagrees with Wallace et al. (1994) findings that there is a negative association between disclosures and liquidity level of a company and Belkaoui and Kahl (1978) findings that there is no association between liquidity and the level of disclosures.

Higher liquidity companies are likely to disclose more social information than lower liquidity companies because they have stronger incentives to do so. They are motivated by the need to publish their strong status in order to enhance their reputation (Abd-El Salam \& Weetman, 2003). On the other hand, some argue that, in order to satisfy the information requirements of stakeholders, managers of low liquid companies may publish more information in their annual reports (Hussainery, Elsayed, \& Razik, 2011).

\section{Industry}

The study found a positive association between the industry profile of a company and the CSD level. This finding is consistent with Patten (1991), Roberts (1992) and Hackston and Milne (1996) who found a positive association between CSD and the type of industry in which the company operates. 
The fact that the industry in which a company operates in influences the level of CSD can be explained by the stakeholder pressure and associated political costs (Brammer \& Millington, 2006). Companies that have a high environmental impact receive more attention from the government and other lobby groups and therefore likely to disclose more social information (Deegan \& Gordon, 1996).

\section{Ownership}

The regression results indicate that the more dispersed the ownership of the company, the more likely that the company will disclose more social responsibility information. This finding agrees with Roberts (1992) and Ullmann (1985) that the degree to which ownership is concentrated in the hands of many investors influences CSD. In order to reduce information asymmetries among the owners and management, corporations with more dispersed ownership are likely expected to disclose more social information (Prencipe, 2004). This can be explained by the fact that where there are many shareholders, there is likely to be a higher level of accountability which leads to disclosure of more social information (Ghazali, 2007). This is because there is likely to be more conflict of interest between owners and managers where ownership is widely dispersed and this leads to increased pressure for more disclosures (Jensen \& Meckling, 1976; Cullen \& Christopher, 2002). This finding supports the agency theory in explaining why companies disclose social responsibility information.

\section{Gearing}

Gearing was found not affect the level of CSD. Findings by different researchers are varied. That gearing level does not affect CSD is supported by Purushothaman et al. (2000), who argue that, because of their close relationships with their creditors, companies with high gearing level are unlikely to disclose a lot of social information. This is because they can use other means of disclosures.

This finding, however, does not agree with Schipper (1981) who argues that high geared firms are likely to provide more information than other companies because their creditors want to know about the company. Therefore, management increases the level of non-financial disclosures because of the demand by such stakeholders (Joshi \& Gao, 2009). Companies with a high gearing are also likely to disclose more information in order to reduce their agency cost and their cost of capital (Jensen \& Meckling, 1976). 


\section{Country of origin}

Country of origin was found not to affect the level of CSD in Kenya. This contradicts studies by researchers such as Jahamani (2003), and, Stanwick and Stanwick (2006), who found an association between the level of social disclosures and the country of origin of the company.

The finding that country of origin does not affect CSD can be explained the fact that Kenya is one of the country in Africa with many multinationals operating and others have their regional offices. This means that international business practices have been adopted by the local companies as they try to mimic the practices of the multinationals. This supports the institutional theory.

And so, one would expect greatest disclosures in large companies, that are highly profitable, more liquid, with more diverse ownership and from highly visible industries.

\section{Limitations of the Study}

Though an attempt has been made to use a longitudinal study, the time covered is short: only 6 years. A study that covers a longer period can help reveal more information of the CSD practise in Kenya. This study, however, covers a longer period than most CSD studies that are crosssectional.

The sample consisted of only the 54 companies listed on the Nairobi Securities Exchange (NSE). Because these are the top companies in Kenya, they are the most likely to make social responsibility disclosures. The study, therefore, is limited in the sense that it did not include companies that are small and are not closely monitored by the Capital Markets Authority (CMA).

In this study, only annual reports were used. According to Unerman (2000) annual reports may not capture all the information disclosed by a company because companies may have used other media, such as websites and stand-alone reports. Use of annual reports, however, is consistent with many CSD studies due to the fact that they are the most important documents.

Content analysis was used for this study. Use of content analysis can be criticized for being subjective because people can interpret the same information differently. To minimize errors an independent evaluator was used analyse the information and the result compared with the findings of the main researcher. The independent evaluator was an accountant with one of the main auditing firm with good understanding of CSD. This was meant to make the data obtained more reliable.

Only listed companies were used in this study. Listed companies because of their visibility are likely to disclose more social information as 
compared to unlisted companies. It is, however, important to note that information on listed companies is easier to obtain.

\section{Further Research}

Investigation should be done on corporate social responsibility information disclosures in reports other than the annual reports. This is because as CSD develops, more and more reports apart from the annual reports will disclose more social responsibility information. This research only covered companies listed on the stock market. Further research should be conducted into companies that are not listed on the stock market so as to compare the findings of the listed companies and those of others.

\section{References:}

1. Abd-El Salam, H., \& Weetman, P. (2003). Introdcuting international accounting standards to an emrging capital markets: relative familiarity and language eefect in Egypt. Journal of International Accounting, Auditing and Taxation, 12, 63-84.

2. Abu-Nasar, M., \& Rutherford, B. (1994). Prepare's attitude to financial reporting in less developed countries with moderately sophisticated capital markets: the case of Jordan. The International Journal of Accounting, 30(2), 129-138.

3. Adams, C., Hill, C., \& Roberts, C. (1998). Corporate social reporting practices in Western Europe: legitimating corporate behavior? The British Accounting Review, 30(1), 1-21.

4. Ahmed, K., \& Courtis, J. (1999). Associations between corporate characteristics and disclosures level in annual reports: A metaanalysis. The British Accounting Review, 31(1), 35-61.

5. Ahmed, K., \& Nicholas, D. (1994). The impact of non-financial company characteristics on mandatory disclosure compliance in developing countries: The case of Bangladesh. International Journal of Accounting, 29(1), 62-77.

6. Akerlof, G. (1970). The market for "lemons": Quality uncertainty and the market mechanism. Quartely Journal of Economics, 84, 488-500.

7. Archambault, J., \& Archambault, M. (2003). A multidimensional test of determinants of corporate disclosure. International Journal if Accounting, 38, 173-194.

8. Barako, D. (2007). Determinants of voluntary disclosures in Kenyan companies annual reports. African Journal of Business Management, 1(5), 113-128.

9. Belkaoui-Riahi, \& Kahl, A. (1978). Corporate Financial Disclosures in Canada. Vancouver: Canadian Certified General Accountants Association. 
10. Botosan, C. (1997). Disclosure level and the cost and the cost of equity capital. The Accounting Review, 72(3), 323-349.

11. Braam, G., \& Borghans, L. (2010). Board and auditor interlocks and voluntary disclosure in annual reports. Nijmegen, Netherlands: Radbound University.

12. Bradbury, M. (1990). The incentives for voluntary audit committee formation. Journal of Accounting and Public Policy, 9(1), 19-36.

13. Bradbury, M. (1992). Voluntary disclosure of financial segment data: New Zealand evidence. Accounting and Finance, 32(1), 15-26.

14. Brammer, S., \& Millington, A. (2006). Firm size, organizational visibility and corporate philanthropy: an empirical analysis. Business Ethics European Review, 15(1), 6-18.

15. Brammer, S., \& Pavelin, S. (2006). Voluntary environmental disclosures by large UK companies. Journal of Business Financial Accounts, 33(7/8), 1168-1188.

16. Branco, M., \& Rodrigues, L. (2006). Communication of corporate social responsibility by Portuguese banks. A legitimacy theory perspective. Corporate Communications: An international Journal, 11(3), 232-248.

17. Branco, M., \& Rodrigues, L. (2008). Factors influencing social responsibility disclosure and Portuguese companies. Journal of Business Ethics, 83(4), 685-701.

18. Buhr, N. (2007). Histories of and ratonales for sustainable reporting. In J. Unerman, J. Bebbington, \& B. O'Dwyer (Ed.), Sustainability, Accounting and Accountability (pp. 57-69). London: Routledge.

19. Bukh, P., Gormses, P., \& Mouritsen, J. (2001). Disclosure of intellectual capital indicators in Danish IPO prospectus. Working paper. Aarhus: Aarhus School of Business.

20. Burritt, R., \& Schaltegger, S. (2010). Sustainability accounting and reporting: fad or trend. Accounting, Auditing \& Accountability Journal, 23(7), 829-846.

21. Carson, E., \& Simnett, R. (1997). Voluntary Disclosure of Corporate Governance Practices. Sydney: University of New South Wales.

22. Chen, C., \& Jaggi, B. (2000). Association between independent noneecutive directors, family control and financial disclosures in Hong Kong. Journal of Accounting and Public Policy, 19(4-5), 285-310.

23. Chow, C., \& Wong-Boren, A. (1987). Voluntary financial disclosure by Mexican corporations. The Accounting Review, 62(3), 533-541.

24. Connelly, J., \& Limpaphayom, P. (2004). Environmental reporting and firm performance: evidence from Thailand. The Journal of Corporate Citizenship, 13, 137-149. 
25. Cooke, T. (1989). Voluntary corporate disclosure by Swedish companies. Journal of International Financial Management and Accounting, 1, 171-195.

26. Cowen, S., Ferreri, L., \& Parker, L. (1987). The impact of corporate characteristics on social responsibility disclosure: A typology of frequency-based analysis. Accounting, Organization and Society, 12(2), 111-122.

27. Crawford, E., \& Williams, C. (2010). Should corporate governance be voluntary or mandatory? Evidence from the banking sector in France and the United States. Corporate Governance, 10(4), 512526.

28. Cullen, L., \& Christopher, T. (2002). Governance disclosures and firm characteristics of listed Australian mining companies. International Journal of Business Sudies, 10(1), 37-58.

29. DeAngelo, L. (1981). Audit size and audit quality. Journal of Accounting and Economics, 3(3), 183-199.

30. Deegan, C. (2002). The legitimising effect of social and environmental disclosures-a theoritical foundation. Acounting, Auditing and Accountability Journal, 15(3), 282-312.

31. Deegan, C., \& Gordon, B. (1996). A study of the environmental disclosure policies of Australian corporations. Accounting \& Business Research, 26(3), 187-199.

32. Deegan, C., Rankin, M., \& Tobin, J. (2002). An examination of the corporate social and environmental disclosures of BHP from 19831997: a test of legitimacy theory. Accounting, Auditing and Accountability Journal, 15(3), 312-343.

33. Depoers, F. (2000). A cost benefit study of voluntary disclosure: Some empirical evidence from French listed companies. European Accounting Review, 9, 245-263.

34. Dowling, \& Pfeffer. (1975). Organisational legitimacy:social values and organizational behaviour. Pacific sociological Review, 18, 122136.

35. Drews, M. (2010). Measuring the business and societal benefits of corporate responibility. Corporate Governance, 10(4), 421-431.

36. Elias, N., \& Epstein, M. (1975). Dimension of corporate social accounting. Management Accounting, 56(9), 39-40.

37. Elijido-Ten, E. (2009). Voluntary environmental disclosures of Malaysian listed companies: an application of the stakeholder theory. AFAANZ Conference. Aldelaide: AFAANZ.

38. Elmogla, M. (2009). Corporate social reporting in a transation economy: The case of Libya. Doctorate Thesis: University of Huddersfield. 
39. Ernst, \& Young. (2002). Corporate Social Responsibility: A Survey of Global Companies. Sydney: Environmental and sustainability Services Group,Ernst and Young.

40. Fama, E., \& Jensen, M. (1983). Separation of ownership and control. The Journal of Law and Economics, 26, 301-325.

41. Firth, M. (1979a). The impact of size, stock market listing, auditors on voluntary disclosure in corporate annual reports. The International Journal of Accouting, 14(1), 57-70.

42. Firth, M. (1979b). The effect of size, stock market listings and auditors on voluntary disclosure in corporate annual reports. Accounting and Business Research, 9(36), 273-280.

43. Forker, J. (1992). Corporate governance and disclosure quality. Accounting and Business Research, 22(86), 111-124.

44. Franks, J., Mayer, C., \& Renneboog, L. (2001). Who disciplines management in poorly performing companies. Journal of Financial Intermediation, 10, 209-248.

45. Freedman, R. (1983). Strategic management: A stakeholder approach. Advances in Strategic Management, 1, 31-60.

46. Gao, Y. (2009). Corporate social performance in China: Evidence from large companies. Journal of Business Ethics, 89(1), 23-35.

47. Garcia-Meca, E., \& Martinez, I. (2005). Assessing the quality of disclosure on intangibles in the Spanish capital market. European Business Review, 17, 305-313.

48. Ghazali, N. (2007). Ownership structure and corporate social responsibility Disclosure: Some Malaysian evidence. Corporate Governance, 7(3), 251-266.

49. Giner, B. (1997). The influence of company characteristics and accounting regulation on informaion disclosed by Spanish firms. European Accounting Review, 6(1), 45-68.

50. Gray, R., \& Bebbington, J. (2007). Corporate sustainability,accounting and the pursuit of the impossible dream. In G. Atkinson, S. Dietz, \& E. Numeyer (Ed.), Handbook of sustainable development. Cheltenham: Edward Elgar.

51. Gray, R., Owen, D., \& Adams, C. (1996). Accounting and accountability: changes and challenges in corporate social and environmental reporting. London: Prentice-Hall.

52. Gujarati, D. (2003). Basic Econometrics. New York: McGraw-Hill.

53. Guthrie, J., \& Parker, L. (1989). Corporate social reporting: a rebuttal of legitimacy theory. Accounting and Business Research, 9(76), 343352 . 
54. Hackston, D., \& Milne, M. (1996). Some determinants of social and environmental disclosures in New Zealand companies. Accounting, Auditing and Accountability Journal, 9(1), 77-108.

55. Halme, M., \& Huse, M. (1997). The influence of corporate governance, industry and country factors on environmental reporting. Scandavian Journal of Management, 13(2), 137-157.

56. Haniffa, R., \& Cooke, T. (2005). The impact of culture and governance on corporate social reporting. Journal of Accounting and Public Policy, 24, 391-430.

57. Hausman, J. (1978). Specification tests in econometrics. Econometrika, 46, 1273-1291.

58. Ho, S., \& Wong, K. (2001a). A study of corporate disclosure practice and effectiveness in Hong Kong. Journal of International Financial Management and Accounting, 12(1), 75-102.

59. Ho, S., \& Wong, K. (2001b). A study of the relationship between corporate governance structures and the extent of voluntary disclosure. Journal of International Accounting, Auditing \& Taxation, 10, 139-156.

60. Hsioa, C. (2003). Analysis of Panel Data (Vol. 2). Cambridge: Cambridge University Press.

61. Hussainery, K., Elsayed, M., \& Razik, M. (2011). Factors affecting corporate social responsibility disclosure in Egypt. Corporate Ownership and Control Journal, 8(4), 432-443.

62. Inchausti, B. (1997). The influence of company characteristics and accounting regulation on information disclosed. European Accounting Review, 6(1), 45-68.

63. Jahamani, Y. (2003). Green accounting in developing countries: the case of UAE and Jordan. Managerial Fnance, 29(8), 37-45.

64. Jensen, \& Meckling. (1976). Theory of the firm: managing behaviour, agency costs and ownership structure. Journal of financial economics, 3(3), 305-360.

65. Joshi, P., \& Gao, S. (2009). Multinational corporate social and environmental disclosures (CSED) on web sites. International Journal of Commerce \& Management, 19(1), 27-44.

66. Kaptein, M. (2007). Ethical guidelines for compiling corporate social reports. Journal of Corporate Citizenship, 27, 71-90.

67. Kaptein, M., \& Van Tulder, R. (2003). Towards effective stakeholder dialogue. Business and Society Review, 108, 203-224.

68. King, A., \& Lenox, M. (2001). Does it really pay to be green? Accounting for strategy selection in relationship between environmental and finance performance. Journal of Industrial Ecology, 5(1), 105-116. 
69. Kohler, U., \& Kreuter, F. (2009). Data Analysis Using Stata (2 ed.). College Station, Texas: Stata Press.

70. Lang, M., \& Lundholm, R. (1993). Cross-sectional determinants of analysts ratings of corporate disclosures. Journal of Accounting Research, 31(2), 246-271.

71. Lim, Y., Talha, M., Mohamed, J., \& Sallehhuddin, A. (2008). Corporate social responsibility disclosure and corporate governance in Malaysia. International Journal of Behavioural Accounting and Finance, 1(1), 67-89.

72. Makris, P. (1996). The role of accounting in handling and reporting enviornmental effects. PhD Thesis. University of Glamorgan.

73. McKinnon, J., \& Dalimunthe, L. (1993). Voluntary disclosure of segment information by Asutralian diversified companies. Accounting and Finance, 33(1), 33-50.

74. McMullen, D. (1996). Audit committee performance: an investigation of the consequencies associated with audit committee. Auditing, 15(1), 87-103.

75. Melis, A. (2004). Financial reporting, corporate communication and governance. Corporate ownership \& Control, 1(2), 31-37.

76. Milne, M., \& Patten, D. (2002). Securing organization legitimacy: An experimental decision case examining the impact of environmental disclosures. Accounting, Auditing and Accountability Journal, 15(3), 372-405.

77. Narayanan, V., Pinches, G., \& Kelm, K. (2000). The influence of voluntary disclosed qualitative information. Strategic Management Journal, 21(7), 707-722.

78. Naser, K. (1998). Comprehensiveness of disclosure of non-financial companies listed on the Amman financial market. International Journal of Commerce and Management, 2(8), 88-119.

79. Ness, K., \& Mirza, A. (1991). Corporate social disclosure: A note on the test of agency theory. The British Accounting Review, 23(3), 211217.

80. O'Donovan. (2002). Environmental disclosure in the annual report: extending the applicability and predictive power of legitimacy theory. Accounting, Auditing and Accountability, 15(3), 344-371.

81. Owusu-Ansah, S. (1998). The impact of corporate attributes on the extent of mandatory disclosure and reporting by listed companies in Zimbabwe. The International Journal of Accounting, 33, 605-631.

82. Patten, D. (1991). Exposure, legitimacy, and social disclosure. Journal of Accounting and Public Policy, 10(4), 297-308.

83. Pratten, J., \& Mashat, A. (2009). Corporate social disclose in Libya. Social Responsibility Journal, 5(3), 311-327. 
84. Prencipe, A. (2004). Proprietary costs and determinants of voluntary segement disclosure: Evidence from Italian listed companies. European Accouning Review, 13(2), 319-340.

85. Purushothaman, M., Tower, G., Hancock, G., \& Taplin, R. (2000). Determinants of corporate social reporting practices of listed Singapore companies. Pacific Accounting Review, 12(2), 101-133.

86. Raar, J. (2002). Environmental initiatives: towards triple-bottom line reporting. Corporate communications, 7(3), 169-183.

87. Ratanajongkol, S., Davey, H., \& Low, M. (2006). Corporate social reporting in Thailand. Qualitative Research in Accounting and Management, 3(1), 67-83.

88. Roberts, R. (1992). Determinants of corporate social responsibility disclosure: an application of stakeholder theory. Accounting, Organizations and Society, 17(6), 595-612.

89. Salama, A., Cathcart, A., Andrews, R., \& Hall, R. (2006). Disclosure regulation and accounting education in the UK: Moving towards corporate accountability 252 and transparency. Social Responsibility Journal, 2(3-4), 251-260.

90. Schipper, K. (1981). Discussion of voluntary corporate disclosure: The case of interim reporting. Journal of Accounting Research, 19 (Supplement), 85-88.

91. Silberhorn, D., \& Warren, R. (2007). Defining corporate social responsibility: a view from big companies in German and UK. European Business Review, 19(5), 352-372.

92. Singhvi, S. (1967). Corporate disclosure through annual reports in the USA and India. Doctoral Dissertation, Columbia University.

93. Stanwick, P., \& Stanwick, S. (2006). Corporate environemtal disclosure: a longitudinal study of Japanese firms. Journal of American Academy of Business, 9(1), 1-7.

94. Sternberg, E. (1997). The defects of the stakeholders theory. Corporate Governance-An international Review, 5(1), 3-10.

95. Tarmizi, A. (2007). Corporate Governance of Family Firms and Voluntary Disclosures: The Case of Indonesian macturing firms. PhD Thesis, University of Western Australia.

96. Thakor, A. (1993). Information, investment horizon, and price reactions. The Journal of Financial and Quantitative Analysis, 28(4), 459-482.

97. Ullmann, A. (1985). Data in search of a theory: A critical examination of the relationships among social performance, social disclosure, and economic performance of US firms. Academy of Management Review, 10(3), 540-557. 
98. Unerman, J. (2000). Methodical issues - reflections on quantification in corporate social reporting content analysis. Accounting, Audtiting \& Accountabiliuty Journal, 13(5).

99. Uwalomwa, U. (2011). Corporate social and enviornmental disclosure in Nigeria: A comparative study of the building material and Nrewery Industry. International Journal of Business and Management, 6(2), 258-264.

100. Walker, D., Michael, P., \& Urmila, T. (2007). Environmental management systems: Information management and corporate responsibility. Journal of facilities management, 5, 49-61.

101. Wallace, R., \& Naser, K. (1995). Firm-specific determinants of comprehensiveness of mandatory disclosures in the Corporate Annual reports of firms on the stock exchange of Hing Kong. Journal of Accounting and Public Policy, 14, 311-368.

102. Wallace, R., Nase, K., \& Mora, A. (1994). The relationship between the comprehensiveness of annual reports and firm characteristics in spain. Accounting and Business Research, 25(97), 41-53.

103. Watts, R., \& Zimmerman, J. (1986). Positive Accounting Theory. New Jersey: Prentice Hall.

104. Williams, S. (1998). Voluntary Environment and Social Accounting Disclosure Practices in Asia-Pacific Region. Perth: Murdoch University.

105. Zadek, S. (2001). The civil corporation:The new economy of corporate citizenship. London: Earthscan. 